
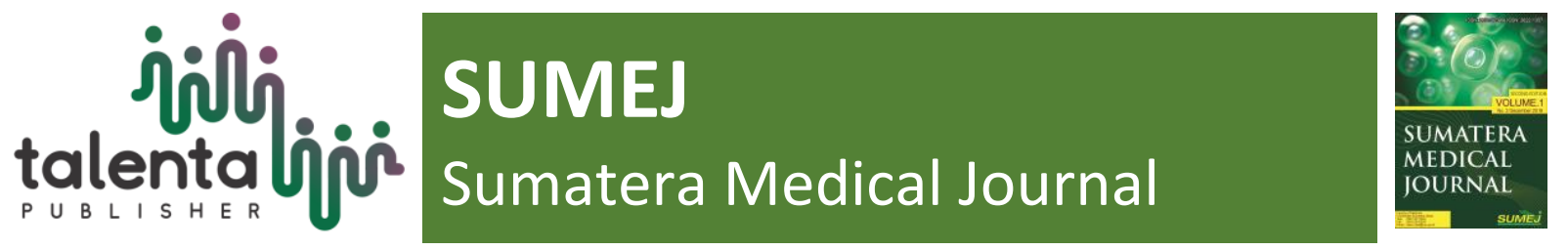

\title{
Relationship of Advanced Paternal Age and Onset of Schizophrenia
}

\author{
Arsusy Widyastuty ${ }^{1^{*}}$, Dapot P Gultom ${ }^{2}$, Muhammad Surya Husada ${ }^{3}$ \\ ${ }^{1,2}$ Department of Psychiatry, Faculty of Medicine Universitas Sumatera Utara, Indonesia \\ ${ }^{3}$ Post graduate of Department of Psychiatry, Faculty of Medicine Universitas Sumatera Utara, Indonesia
}

\begin{abstract}
Background: Increased paternal age has been associated with an increased risk of spontaneous abortion, premature birth, infant mortality, congenital malformations, childhood cancer, epilepsy, autism, bipolar and schizophrenia in offspring. The biological mechanisms behind this relationship are not known but may be associated with de novo mutations and epigenetic changes in male cells with short and long term health consequences for their offspring. Males are responsible for most of the new mutations in the gene group, to the permanent distribution of reproductive cells and the number of mutations increases significantly with age. The aim of the study to determine the correlation between paternal age and onset of schizophrenia. Method: This study was correlation analysis with cross sectional approach with the subject is 92 schizophrenia patients. Analysis of the data using statistical test that is chi-square. The Study Findings Showed There Was Significant Correlation Between Paternal Age with Schizophrenic Aged Onset Of $0.001(\mathrm{P}<0.05)$.
\end{abstract}

Keyword: Paternal age, Schizophrenia

Abstrak. Peningkatan usia ayah telah dikaitkan dengan peningkatan risiko aborsi spontan, kelahiran prematur, kematian bayi, malformasi kongenital, kanker anak, epilepsi, autisme, bipolar dan skizofrenia pada keturunan. Mekanisme biologis di balik hubungan ini tidak diketahui tetapi mungkin terkait dengan mutasi de novo dan perubahan epigenetik pada sel laki-laki dengan konsekuensi kesehatan jangka pendek dan panjang untuk keturunan mereka. Pria bertanggung jawab untuk sebagian besar mutasi baru dalam kelompok gen, ke distribusi permanen sel-sel reproduksi dan jumlah mutasi meningkat secara signifikan dengan usia. Tujuan dari penelitian untuk menentukan korelasi antara usia ayah dan onset skizofrenia. Metode: Penelitian ini merupakan analisis korelasi dengan pendekatan cross sectional dengan subjek penelitian adalah 92 pasien skizofrenia. Analisis data menggunakan uji statistik yaitu chi-square. Hasil penelitian menunjukkan ada hubungan yang signifikan antara usia ayah dengan onset usia skizofrenia 0,001 ( $p<0,05)$.

Kata Kunci: Usia Ayah, Skizofrenia

Received 2 January 2019 | Revised 17 January 2019| Accepted 31 January 2019

\section{Introduction}

Schizophrenia is a severe and chronic mental disorder with a high prevalence (about $1 \%$ of the general population). It usually starts before the age of 25 , lasts all life, and about everyone from all social classes [1]. Environmental factors associated with schizophrenia include winter

*Corresponding author at: Faculty of Medicine, Universitas Sumatera Utara, Medan, Indonesia 
parturition, maternal stress during pregnancy, second trimester and postnatal infection, immigration, residency in urban areas, and paternal occupations and age [2]. Increased paternal age has been associated with an increased risk of spontaneous abortion, premature birth, infant, mortality, congenital malformations, childhood cancer, epilepsy, autism, bipolar and schizophrenia in the offspring [3].

Relationship between the paternal age and genetic abnormality was first discovered in 1800 and the origin of the relationship between age and genetic disease is known as acondroplasia in 1950 [4]. The approximate basis of the father's age effect lies in increasing the frequency of new gene mutations in cells at age older father's [5].

In most western sociaties the average father's age is increasing, reflecting changes in professional and social life. The literature shows that in the England and Wales of 1993-2003, the rate of the older paternal age (35-54 years) increased from 25 percent to 40 percent, and the mean paternal age increased from 29.2 years to 32.1 year [6]. Several cohort studies from Israel, America, Denmark, Sweden proved strong evidence of a link between increased paternal age to schizophrenia risk in offspring. There was an increased risk of schizophrenia ( 3 to 4 times) in offspring whose father was over 50 years at a time of exposure compared to the offspring whose father was in his 20s [7].

Advanced paternal age is associated with accumulated environmental insults over time and is strongly associated with reductions in fertility due to impaired spermatogenesis. It is also well known that in males, gene mutations are high due to the increased frequency of cell division over the life course. The association of schizophrenia with Paternal age was stronger in people having a family history of schizophrenia, supporting the hypothesis that new collected genetic mutations in older dad cells can play an important role in the aetiology of schizophrenia. This raises the idea that sperm cell division occurs during male life results in high mutation rates and cytogenic abnormalities in older male sperm. In addition, exposure to heat can also cause an increase in the mutation of spermatozoa [6].

The researchers proposed the dysregulation of epigenetics as a possible etiology. Epigenetic processes utilize DNA methylation and demethylation, as well as changes in chromatin structure, to control gene expression [5]. Epigenetic processes could be compromised in the sperm of older fathers and these mechanisms can contribute to the increased risk for schizophrenia in the offspring of older father. The explanations behind intra- and inter-individual epigenetic variability in the male cells, is that the epigenetic signal are generally reprogrammed in the cell, although it appears that such reprogramming may not be fully complete across all regions of the genome [5]. Hypermethylated repetitive and elements in the genome are often not efficiently reprogrammed, this may lead to de novo structural mutations, which are often associated with repetitive of DNA sequences motifs, may be subjected to differential epigenetic reprogramming, associating both 
mutagenic and epigenetic processes in the phenotypic manifestations of increased paternal age [6].

A study was done by Colombia university researchers on 87,907 cases, showed that the prevalence in offspring whose father were age 45-49 years is twice in comporison with who are under 25 and in fathers aged who are up to 50 years is triple than who are under 25 year. This study shows that 26.6 percent of all schizophrenia is a stronger relationship to paternal age, while there is no relation for maternal transmission of the disease [8].

Malaspina et al., Reported that the paternal age at birth of sporadic cases averaged 4.7 years older than familial cases of schizophrenia, attributed approximately $27 \%$ of the sporadic cases to paternal age, and likely due to de novo mutations [2].

\section{Methodology}

\subsection{Study design}

Type of research used correlative analytic study with Cross-sectional study approach, which assessed the correlation between paternal age and age onset in Schizophrenic Patients.

\subsection{Setting and sample}

This research was conducted at the inpatient installation of Mental Hospital Prof. dr. M. Ildrem Medan in the period December 2014 - February 2015. The population in this study were schizophrenic patients, while the affordable population were schizophrenic patients at the Inpatient Installation of Mental Hospital Prof. dr. M. Ildrem Medan. Sampling method in this research is by nonprobability sampling type consecutive sampling that is all subjects that come and meet the election criteria as much as 92 people.

\section{Result}

The demographic features of schizophrenic patients are presented in Table 1. Variables with categorical scales are presented in frequency and proportion.

Table 1 Distribution of Research Subjects Based on Demographic Characteristics 


\begin{tabular}{lcc}
\hline Variable & $\mathrm{N}$ & $\%$ \\
\hline Gender of schizophrenic patients & & \\
$\quad$ Man & 40 & 43,48 \\
$\quad$ Women & 52 & 56,52 \\
Patient's onset age & & \\
$\quad<25$ & 38 & 41,3 \\
$\quad 225$ & 54 & 58,7 \\
Father's education & & \\
Primary school & 30 & 32,6 \\
$\quad$ Junior high school & 32 & 34,78 \\
Senior high school & 20 & 21,74 \\
University & 10 & 10,86 \\
Paternal age & & \\
$\quad<45$ & 40 & 43,48 \\
$\quad \geq 45$ & 52 & 56,52 \\
Employment status & & \\
Paid employment & 72 & 78,26 \\
Not employment & 20 & 21,74 \\
\hline
\end{tabular}

Table 1 show that Based on the demographic characteristics of the study sample, most schizophrenic patients were found in the age group $\geq 25$ years old as many as 54 people (58.7\%), female $52(56.52 \%)$, Junior high school graduate father as much as 32 people (34.78\%), paternal age in the age group 45-54 years old as many as 42 people (45.6\%), and working adult as many as 72 people $(21.74 \%)$.

Table 2 Relationship between the paternal age and onset schizophrenic patients

\begin{tabular}{ccccc}
\hline \multicolumn{5}{c}{ Age of onset } \\
Paternal age & $<25$ & Total & $\mathrm{p}$ \\
& $\mathrm{n}(\%)$ & $\mathrm{n}(\%)$ & & \\
\hline$<45$ & 0 & $38(41.3)$ & $38(41.3)$ & 0.001 \\
$\geq 45$ & $52(56.53)$ & $2(2.17)$ & $54(58.7)$ & \\
\hline Total & $52(56.53)$ & $40(43.47)$ & $92(100.0)$ & \\
\hline
\end{tabular}

Table 2 showed in this study, paternal age $<45$ years old was found in as much as 38 people (41.3\%), and paternal age group $\geq 45$ years old in as many as 52 people $(56.53 \%)$, and the study showed there was a significant relationship between Paternal age and onset of age in schizophrenic is $0.001(\mathrm{p}<0.05)$.

\section{Discussion}

This study, according to a study conducted by Victoria O, et al, in Iran 2009 , there was a significant relationship between paternal age and the occurrence of schizophrenic disorder. Another study that was by Rachka in 574 schizophrenic patients also showed increased risk of schizophrenia in older fathers. Paternal age was one of the etiologic factors for schizophrenia. Many studies suggested declared the relationship between advanced paternal age and prevalence 
of schizophrenia in a family, in these survey the linear correlation. More than half a century ago, a study conducted by the Book suggested that de novo mutation might cause genitival defect contributed responsibility of schizophrenia disorder, and also it is observed that increased paternal age is associated with de novo mutation [8].

Miller et al revealed that relative risk in the oldest fathers ( $\geq 50$ years) was 1.66 compared with younger fathers. The population attributable risk percentage was $10 \%$ for paternal age of $>30$ years and $5 \%$ for paternal age of $<25$ years. The results of these studies support the theory that accumulating de novo mutations in the germ cells of older fathers might contribute to an increased risk of schizophrenia in their offspring [9].

There were 5 studies that mentioned further mutations in the " Paternal germ cell " compared with maternal and in 24 studies show increased paternal age is associated with increased disease due to genomic mutation rate. In 8 studies investigated on 10347 schizophrenic patients showed that paternal age and indicated paternal age as a health risk factor. Offspring of older father have an increased the risk for maternal disorders related to DNA Junctions during Spermatogenesis [8]. It is thought that the spermatogonial stem cell divisions occurring during the life-course of males result in higher mutational rates and cytogenetic abnormalities in the sperm of older men. Perrin et al also hypothesized that the relationship between schizophrenia and advanced paternal age (APA) is related to point mutations during spermatogenesis that occur in increasing frequency as the male ages [6].

\section{Conclusion}

A total of 92 subjects at Mental Hospital Prof. dr. M. Ildrem Medan in December 2014 to February 2015. In conclusion, the present research revealed this study showed a significant correlation between paternal age with schizophrenic onset of $0.001(\mathrm{p}<0.05)$.

\section{Suggestion}

It is expected that the clinician should not only focus on schizophrenic patients, but the father's age should be a consideration of the risk of schizophrenia.

From this study's there is a significant relationship between Paternal age with occurrence of schizophrenia, therefore the patient's family members, especially the father of the patient should be educated about factors that can cause schizophrenia.

It is desirable that this study can be be a reference material for next author or the like in examining other factors related to Paternal age with the risk of schizophrenia that not investigated in this study such as father's personality traits and others. 


\section{REFERENCES}

[1] V. A. Saddock, R. M. Jones, and B. J. Sadock, Study Guide and Self-examination Review for Kaplan and Sadock's Synopsis of Psychiatry. Lippincott Williams \& Wilkins, 2007.

[2] M. Naserbakht, H.-R. Ahmadkhaniha, B. Mokri, and C. L. Smith, "Advanced paternal age is a risk factor for schizophrenia in Iranians," Annals of general psychiatry, vol. 10, no. 1, p. $15,2011$.

[3] J. E. Buizer-Voskamp et al., "Paternal age and psychiatric disorders: findings from a Dutch population registry," Schizophrenia research, vol. 129, no. 2-3, pp. 128-132, 2011.

[4] L. Petersen, P. B. Mortensen, and C. B. Pedersen, "Paternal age at birth of first child and risk of schizophrenia," American Journal of Psychiatry, vol. 168, no. 1, pp. 82-88, 2011.

[5] J. R. Momand, G. Xu, and C. A. Walter, "The paternal age effect: a multifaceted phenomenon," Biology of reproduction, vol. 88, no. 4, pp. 108-1, 2013.

[6] G. M. Bajwa, D. Hasija, S. L. K. Jadapalle, S. Ghaffar, and A. Badr, "Advanced Paternal Age and the Risk of Schizophrenia: A Literature Review," Psychiatric Annals, vol. 41, no. 6, pp. 325-328, 2011.

[7] F. Rasmussen, "Paternal age, size at birth, and size in young adulthood-risk factors for schizophrenia," European journal of endocrinology, vol. 155, no. suppl 1, pp. S65-S69, 2006.

[8] V. Omranifard and G. Asadollahi, "Association between paternal age at birth time and the risk of offspring developing schizophrenia," American Journal of Applied Sciences, vol. 6, no. 1, p. 179, 2009.

[9] Z. Wiener-Megnazi, R. Auslender, and M. Dirnfeld, "Advanced paternal age and reproductive outcome," Asian journal of andrology, vol. 14, no. 1, p. 69, 2012. 